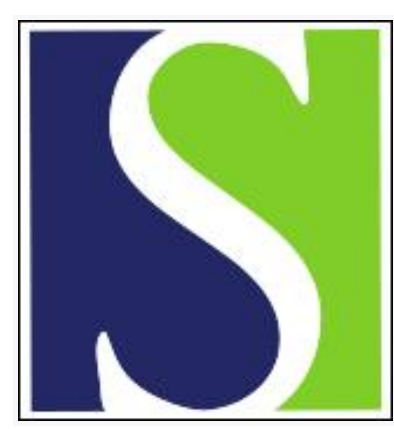

Scand J Work Environ Health 1998;24(1):38-45

https://doi.org/10.5271/sjweh.276

Issue date: Feb 1998

Lead concentrations in tibial and calcaneal bone in relation to the history of lead exposure

by Bergdahl IA, Strömberg U, Gerhardsson L, Schütz A, Chettle DR, Skerfving $\mathrm{S}$

Key terms: blood; calcaneus; occupational exposure; plasma; plasma lead; tibia

This article in PubMed: www.ncbi.nlm.nih.gov/pubmed/9562399

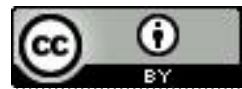




\title{
Lead concentrations in tibial and calcaneal bone in relation to the history of occupational lead exposure
}

\author{
by Ingvar A Bergdahl, PhD, ${ }^{1}$ Ulf Strömberg, PhD, ${ }^{1}$ Lars Gerhardsson, MD, ${ }^{1}$ Andrejs Schütz, PhD, ${ }^{1}$ \\ David $R$ Chettle, PhD, ${ }^{2}$ Staffan Skerfving, $M D^{1}$
}

\begin{abstract}
Bergdahl IA, Strömberg U, Gerhardsson L, Schütz A, Chettle DR, Skerfving S. Lead concentrations in tibial and calcaneal bone in relation to the history of lead exposure. Scand J Work Environ Health 1998;24(1):38-45.
\end{abstract}

\begin{abstract}
Objectives This study tested a simple model of the relationship between the lead concentration in bone (bone- $\mathrm{Pb}$ ), exposure time, and lead in plasma $(\mathrm{P}-\mathrm{Pb})$ and whole blood $(\mathrm{B}-\mathrm{Pb})$ to make it possible to use bone$\mathrm{Pb}$ as a retrospective exposure index.

Methods Seventy-seven active lead workers and 24 referents were studied. The bone- $\mathrm{Pb}$ in tibia (T-Pb) and calcaneus $(\mathrm{C}-\mathrm{Pb})$ was measured by in vivo X-ray fluorescence. $\mathrm{P}-\mathrm{Pb}$ was calculated from $\mathrm{B}-\mathrm{Pb}$ by use of the nonlinear relationship between these variables. Cumulative $\mathrm{B}-\mathrm{Pb}$ (cumB-Pb) and $\mathrm{P}-\mathrm{Pb}$ (cumP-Pb) were calculated to the time of the bone- $\mathrm{Pb}$ measurements. In addition, cumP-Pb was adjusted by applying varying rate constants for the transfer of lead from bone to plasma.

Results There were close linear associations between the lead concentrations in tibia (proportion of variance explained, $\left.\mathrm{R}^{2}=0.78\right)$ and calcaneus $\left(\mathrm{R}^{2}=0.80\right)$, on one hand and the cumB-Pb on the other. The best fit of bone$\mathrm{Pb}$ to the adjusted cumP-Pb $(0.79$ for $\mathrm{T}-\mathrm{Pb} ; 0.82$ for $\mathrm{C}-\mathrm{Pb})$ was obtained for the terminal phase half-times of 13 and 12 years, respectively.

Conclusions The combined data on bone- $\mathrm{Pb}$ and exposure time make it possible to estimate previous mean $\mathrm{P}-\mathrm{Pb}$ and $\mathrm{B}-\mathrm{Pb}$. Such estimates will be valuable in studies of toxic effects on long-term exposed lead workers when data on the intensity of previous exposure are lacking. The use of $\mathrm{P}-\mathrm{Pb}$ in modeling bone- $\mathrm{Pb}$ kinetics is physiologically relevant, but the use of adjusted cumP-Pb, as compared with cumB- $\mathrm{Pb}$, did not significantly change the variance in the relation to bone- $\mathrm{Pb}$.
\end{abstract}

Key terms blood, calcaneus, tibia, occupational exposure, plasma, plasma lead.

Exposure to inorganic lead is a considerable toxicologic problem in the work and general environments in many areas of the world (1). Hence, there is a great need for reliable indicators of exposure and risk. The lead concentration in whole blood $(\mathrm{B}-\mathrm{Pb})$ is currently the most commonly used index, but, due to its rather fast turnover $(2,3)$, it mainly indicates recent exposure.

More than $90 \%$ of the body burden of lead is in the skeleton, where the turnover is slow. For fingerbone, half-times of $7-16$ years have been found $(4,5)$, and for tibia and calcaneus the corresponding value is 27 and 16 years, respectively (6). The concentration of lead in bone (bone- $\mathrm{Pb}$ ) thus reflects long-term exposure $(7,8)$. Bone- $\mathrm{Pb}$ may be determined in vivo by $\mathrm{X}$-ray fluorescence techniques. Mainly, the concentrations in fingerbone $(4,5,7-10)$, tibia $(\mathrm{T}-\mathrm{Pb})$, calcaneus $(\mathrm{C}-\mathrm{Pb})$, and patella $(6,11-18)$, have been studied.

However, most of the knowledge about lead toxicity is based on $\mathrm{B}-\mathrm{Pb}$. Thus the relationship with other exposure markers (eg, $\mathrm{B}-\mathrm{Pb}$ ) must be known before bone- $\mathrm{Pb}$ data can be evaluated. Therefore modeling on the basis of data from lead-exposed humans is required (19).

Bone- $\mathrm{Pb}$ has been shown to correlate well with simple, time-integrated cumulative $\mathrm{B}-\mathrm{Pb}$ (cumB-Pb) $(6-8,12,15$, $16,20,21)$. The correlation is somewhat surprising in that it

1 Department of Occupational and Environmental Medicine, Lund University, University Hospital, Lund, Sweden.

2 Department of Physics and Astronomy, McMaster University, Hamilton, Ontario, Canada.

Reprint requests to: Ingvar A Bergdahl, Department of Occupational and Environmental Medicine, University Hospital, S-221 85 Lund, Sweden.

Correspondence to: Dr Staffan Skerfving, Department of Occupational and Environmental Medicine, University Hospital, S-221 85 Lund, Sweden. [e-mail: Staffan.Skerfving@ymed.lu.se] 
would mean that lead is stored in bone, but never released. Therefore, Börjesson et al (8) calculated an adjusted cumB-Pb with respect to the turnover rate of lead in the skeleton. It gave a somewhat better prediction of bone- $\mathrm{Pb}$ than the unadjusted cumB-Pb.

The assumption of a rectilinear relationship between bone- $\mathrm{Pb}$ and cumB-Pb or adjusted cumB-Pb is, however, hard to justify, since there is recent, strong evidence of a markedly nonlinear, close association between $\mathrm{B}-\mathrm{Pb}$ and the lead concentration in plasma (P-Pb), the magnitude of which is only $1 / 100$ of $\mathrm{B}-\mathrm{Pb}$ levels $(22,23)$. The nonlinear relation between $\mathrm{B}-\mathrm{Pb}$ and $\mathrm{P}-\mathrm{Pb}$ is probably an effect of gradual saturation of the strongest binding sites for lead in the red cells, localized on the enzyme $\delta$-aminolevulinic acid dehydratase $(24,25)$. Accordingly, $\mathrm{P}-\mathrm{Pb}$ is probably better than $\mathrm{B}-\mathrm{Pb}$ (mainly reflecting lead in blood cells) as a predictor of the lead deposition rate into the skeleton.

The use of true $\mathrm{P}-\mathrm{Pb}$ data in metabolic models has hitherto not been possible due to analytical problems at low lead levels. This has recently changed in that determinations of $\mathrm{P}-\mathrm{Pb}$ by inductively coupled plasma mass spectrometry (ICP-MS) can be performed precisely and probably also accurately, and contamination and hemolysis seem to be no serious obstacles (22). It should also be possible to use P$\mathrm{Pb}$ values calculated from historical $\mathrm{B}-\mathrm{Pb}$ values by use of the close relation between $\mathrm{B}-\mathrm{Pb}$ and $\mathrm{P}-\mathrm{Pb}$ established recently (23).

The aim of the present study was to test a model for the relationship between lead in tibia and calcaneus and the historic $\mathrm{B}-\mathrm{Pb}$, with focus on $\mathrm{P}-\mathrm{Pb}$ as the estimate of exposure. In addition, we present information on the kinetics of lead in the skeleton.

\section{Study population}

The study comprised 77 male workers from a secondary lead smelter founded in 1942. Scrap lead from telephone cables and lead storage batteries forms the largest single group of raw material. In addition, various types of lead-antimony and lead-tin alloys, as well as unalloyed lead, are handled. The workers have been followed by regular $\mathrm{B}-\mathrm{Pb}$ monitoring since 1968 , with up to 6 determinations per year. The $\mathrm{B}-\mathrm{Pb}$ levels have gradually decreased through the years. For most of the follow-up period, the work force comprised 150 to 160 workers. Due to the introduction of new technology, it has been reduced during the last few years to about 100 . Furthermore, 24 male referents, occupationally unexposed to lead, were included. The $\mathrm{B}-\mathrm{Pb}$ values of the referents were determined once, at the same time as the bone- $\mathrm{Pb}$ concentration was measured. All the bone-Pb measurements were performed in September 1986 (13). Table 1 presents characteristics of the subjects.

All the subjects gave their written consent to participate in the study, and the project was approved by the Ethical Committee of the Lund University.

\section{Methods}

\section{Bone lead}

The bone- $\mathrm{Pb}$ concentrations at the midpoint of the left tibia (T-Pb) and the lower rear portion of the left calcaneus (C$\mathrm{Pb}$ ) were determined simultaneously in vivo by X-ray fluorescence, using a method described in detail elsewhere (26). Gamma rays from an annular ${ }^{109} \mathrm{Cd}$ source were used to excite lead $\mathrm{K} X$-rays. By normalizing the signal for the lead X-ray peak to that of the coherent peak, the mass of lead was related to that of the bone mineral in which it was incorporated. The measurement time was 30 minutes (live time) in both cases. The accuracy has been ascertained by the intercomparison of results obtained by X-ray fluorescence and atomic absorption spectrometry (AAS) (27). The precision (expressed as the standard deviation) for tibial and calcaneal measurements ranged from \pm 6 to \pm 11 and from \pm 12 to $\pm 30 \mu \mathrm{g} / \mathrm{g}$ bone mineral, respectively.

At low levels of bone- $\mathrm{Pb}$, negative estimates of the bone$\mathrm{Pb}$ can be obtained, due to the nature of the registration method. We have consistently included values below the minimum detectable concentration (a bone- $\mathrm{Pb}$ with a magnitude equal to twice its overall uncertainty, allowing for variance in both peak and background) as well as negative estimates of bone- $\mathrm{Pb}$ levels in the analyses in order to be able to calculate means without introducing systematic errors (18).

Table 1. Characteristics of the 77 workers from a secondary lead smelter and 24 referents. The determinations of bone lead (bone$\mathrm{Pb})$ were made in 1986.

\begin{tabular}{|c|c|c|c|c|}
\hline Variable & Median & Range & $\begin{array}{l}\text { Lower } \\
\text { quartile }\end{array}$ & $\begin{array}{l}\text { Upper } \\
\text { quartile }\end{array}$ \\
\hline \multicolumn{5}{|c|}{ First year of employment } \\
\hline Exposed workers & 1977 & $1945-1986$ & 1971 & 1984 \\
\hline \multicolumn{5}{|l|}{$\begin{array}{l}\text { Age (years) at start } \\
\text { of employment }\end{array}$} \\
\hline Exposed workers & 30 & $17-51$ & 23 & 39 \\
\hline \multicolumn{5}{|c|}{$\begin{array}{l}\text { Year of first blood lead } \\
\text { measurement }\end{array}$} \\
\hline $\begin{array}{l}\text { Exposed workers } \\
\text { Referents }\end{array}$ & $\begin{array}{l}1977 \\
1986\end{array}$ & $\begin{array}{c}1968-1986 \\
-\end{array}$ & 1972 & 1984 \\
\hline \multicolumn{5}{|c|}{$\begin{array}{l}\text { Age (years) at bone-Pb } \\
\text { measurement }\end{array}$} \\
\hline $\begin{array}{l}\text { Exposed workers } \\
\text { Referents }\end{array}$ & $\begin{array}{l}43 \\
49\end{array}$ & $\begin{array}{l}19-65 \\
27-72\end{array}$ & $\begin{array}{l}29 \\
32\end{array}$ & $\begin{array}{l}54 \\
60\end{array}$ \\
\hline \multicolumn{5}{|c|}{$\begin{array}{l}\text { Observed blood lead }(\mu \mathrm{g} / /) \\
\text { at bone- } \mathrm{Pb} \text { measurement }\end{array}$} \\
\hline $\begin{array}{l}\text { Exposed workers } \\
\text { Referents }\end{array}$ & $\begin{array}{r}350 \\
50\end{array}$ & $\begin{array}{l}140-570 \\
29-160\end{array}$ & $\begin{array}{r}300 \\
39\end{array}$ & $\begin{array}{r}420 \\
60\end{array}$ \\
\hline \multicolumn{5}{|c|}{$\begin{array}{l}\text { Estimated plasma lead }(\mu \mathrm{g} / \mathrm{l}) \\
\text { at bone-Pb measurement }\end{array}$} \\
\hline $\begin{array}{l}\text { Exposed workers } \\
\text { Referents }\end{array}$ & $\begin{array}{l}1.66 \\
0.34\end{array}$ & $\begin{array}{l}0.56-5.08 \\
0.31-0.60\end{array}$ & $\begin{array}{l}1.28 \\
0.32\end{array}$ & $\begin{array}{l}2.38 \\
0.36\end{array}$ \\
\hline \multicolumn{5}{|c|}{ Lead in tibial bone $(\mu \mathrm{g} / \mathrm{g})$} \\
\hline $\begin{array}{l}\text { Exposed workers } \\
\text { Referents }\end{array}$ & $\begin{array}{l}25 \\
10\end{array}$ & $\begin{array}{l}-5-193 \\
-6-36\end{array}$ & $\begin{array}{r}15 \\
1\end{array}$ & $\begin{array}{l}49 \\
22\end{array}$ \\
\hline \multicolumn{5}{|c|}{ Lead in calcaneal bone $(\mu \mathrm{g} / \mathrm{g})$} \\
\hline $\begin{array}{l}\text { Exposed workers } \\
\text { Referents }\end{array}$ & $\begin{array}{l}52 \\
11\end{array}$ & $\begin{array}{l}-20-458 \\
-12-61\end{array}$ & $\begin{array}{l}19 \\
-3\end{array}$ & $\begin{array}{r}114 \\
24\end{array}$ \\
\hline
\end{tabular}




\section{Whole blood lead}

For the determination of $\mathrm{B}-\mathrm{Pb}$, different methods have been used throughout the years. The details have been reported elsewhere (8). The laboratories involved participated regularly in a governmental quality control program.

\section{Plasma lead}

For each $\mathrm{B}-\mathrm{Pb}$ result (expressed in $\mu \mathrm{g} / \mathrm{l}$ ), a corresponding $\mathrm{P}-\mathrm{Pb}$ (in $\mu \mathrm{g} / \mathrm{l}$ ) was calculated from the function: $\ln (\mathrm{P}-\mathrm{Pb})=$ $0.0052 \cdot \mathrm{B}-\mathrm{Pb}-1.33(1 \mu \mathrm{mol} / \mathrm{l}=207 \mu \mathrm{g} / \mathrm{l})$. This function was derived from the relationship observed in another study, comprising 110 male lead smelter workers and 35 referents (23). The $\mathrm{B}-\mathrm{Pb}$ levels in that study ranged from 9 to $930 \mu \mathrm{g} / \mathrm{l}$, and the $\mathrm{P}-\mathrm{Pb}$ concentrations from 0.20 to $37 \mu \mathrm{g} / \mathrm{l}$. Most of the workers $(\mathrm{N}=90)$ were from the present smelter; 36 of these had participated in the present study a few years earlier. To obtain a better estimate of the function, 20 workers at another secondary lead smelter, with higher exposure, were included in that study (crucial, because of the higher exposure earlier in the present smelter). The function above was derived as the linear regression line after logarithmic transformation of $\mathrm{P}-\mathrm{Pb}\left(\mathrm{R}^{2}=0.94\right)(23)$. The $\mathrm{P}-\mathrm{Pb}$ determinations had been made by ICP-MS after dilution (22), B-Pb by electrothermal atomization AAS.

\section{Annual whole blood and plasma lead}

For each person, the annual mean $\mathrm{P}-\mathrm{Pb}$ and $\mathrm{B}-\mathrm{Pb}$ levels were estimated from 17 years of age until the date of the bone- $\mathrm{Pb}$ measurement. These $\mathrm{P}-\mathrm{Pb}$ and $\mathrm{B}-\mathrm{Pb}$ values were time-integrated, forming cumP-Pb and cumB-Pb. If $\mathrm{B}-\mathrm{Pb}$ observations were missing for a calendar year after the commencement of employment, the annual mean $\mathrm{P}-\mathrm{Pb}$ and $\mathrm{B}-\mathrm{Pb}$ were set equal to that of the next year for which $\mathrm{B}-\mathrm{Pb}$ observations were available. In particular, this procedure implies that the $\mathrm{P}-\mathrm{Pb}$ and $\mathrm{B}-\mathrm{Pb}$ of the workers employed before 1968 were extrapolated as constant levels back to the beginning of their employment.

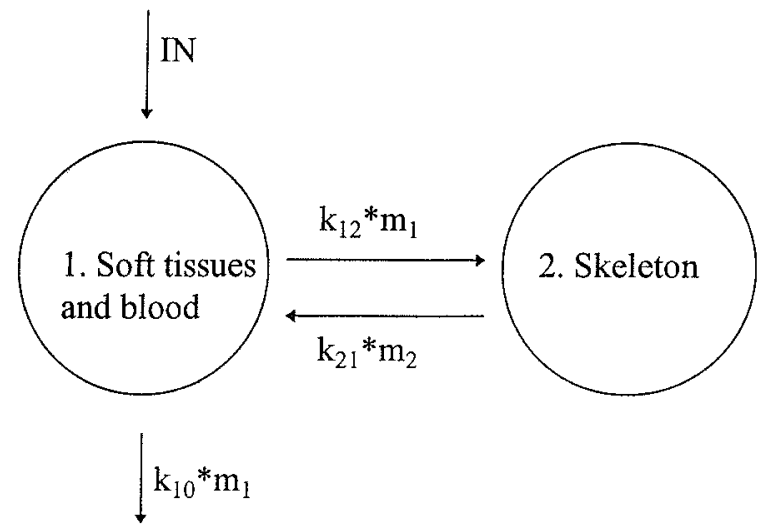

Figure 1. A 2-compartment model with the skeleton, represented by tibia (T-Pb) and calcaneus (C-Pb), as 1 pool, and all other tissues represented by plasma lead $(\mathrm{P}-\mathrm{Pb})$ as the central pool. The arrows represent flows which, with the exception of "IN", can be modeled as a rate constant $(k)$ and the lead content in the pool (m).
The 77 active workers generated 786 person-years from the start of employment until the bone- $\mathrm{Pb}$ measurement in 1986; information on $\mathrm{B}-\mathrm{Pb}$ was available from 724 personyears. A dominating fraction of the 62 person-years with no information on B-Pb were from before 1968 .

So that the $\mathrm{B}-\mathrm{Pb}$ and $\mathrm{P}-\mathrm{Pb}$ concentrations of the workers from 17 years of age to the start of employment, or to the time of bone- $\mathrm{Pb}$ measurement for the referents, could be taken into account, annual "background" $\mathrm{B}-\mathrm{Pb}$ values were estimated (8) on the basis of data from studies of B-Pb in 2441 children during 1978-1994 (28) and 166 occupationally unexposed Swedish adult men in 1984 (29).

\section{Model}

A linear 2-compartment model was adopted with the skeleton as 1 pool and plasma and all other tissues as the central pool (figure 1). The lead content in the skeletal pool was assumed to be proportional to either $\mathrm{T}-\mathrm{Pb}$ or $\mathrm{C}-\mathrm{Pb}$; in the other tissues to $\mathrm{P}-\mathrm{Pb}$ as calculated from $\mathrm{B}-\mathrm{Pb}$.

In the model, we have assumed that (i) the amount of lead deposited in the bone during a year is proportional to the mean $\mathrm{P}-\mathrm{Pb}$ for the same year and (ii) at the time of the bone-Pb measurement this amount had decreased according to the rate constant $k_{21}$, which is related to a "bone-to-plasma half-time". (See the appendix.) Consequently, at the time of the bone- $\mathrm{Pb}$ measurement, the amount of lead remaining from a particular year should be proportional to the mean P$\mathrm{Pb}$ for the same year after adjustment according to the boneto-plasma half-time. Moreover, the total amount of lead remaining in the bone should be proportional to the sum of these adjusted annual mean $\mathrm{P}-\mathrm{Pb}$ values.

To determine which bone-to-plasma half-time was most consistent with our data, we calculated several adjusted cumP-Pb values for each person with various such half-times being applied. For each half-time, a linear regression analysis of measured bone- $\mathrm{Pb}$ versus adjusted cumP-Pb was performed. The value which gave the best fit was selected; the fraction of explained variance $\left(\mathrm{R}^{2}\right)$ was used as the goodness-of-fit statistic. The same procedure was used for the adjusted cumB-Pb value.

The use of $\mathrm{R}^{2}$ for evaluating goodness-of-fit may raise concern due to the scewed distribution of the variables. It would be impossible to adjust for the scewed distribution by a logarithmic conversion of any of the variables since this procedure would violate the model (figure 1). However, the crucial assumptions are that there is a linear relation between the response and predictor variables, and, for each value of the predictor ( $\mathrm{eg}$, adjusted cumP-Pb), the values of the response variable (bone- $\mathrm{Pb}$ ) should have a normal distribution (30). Therefore, the choice of $\mathrm{R}^{2}$ is justified.

Note that the bone-to-plasma half-time represents the halftime for bone- $\mathrm{Pb}$ if $\mathrm{P}-\mathrm{Pb}$ were suddenly to drop to 0 . However, in reality, $\mathrm{P}-\mathrm{Pb}$ decreases gradually after lead exposure ceases, and thus a fraction of lead released from the skeleton 
is redeposited into the skeleton (as a part of the flow represented by $\mathrm{k}_{12} * \mathrm{~m}_{1}$ ) (figure 1 ).

It has been proposed, that the impact of a certain amount of lead on the serum-lead level (and consequently on P-Pb) is larger when it is released from bone, as compared with when the same amount of lead is newly absorbed from external sources (31). However, other data contradict this proposal (32), and therefore no correction for such a difference has been included in the model.

\section{Results}

The median $\mathrm{T}-\mathrm{Pb}$ and $\mathrm{C}-\mathrm{Pb}$ levels were 25 and $52 \mu \mathrm{g} / \mathrm{g}$, respectively, for the lead workers, and 10 and $11 \mu \mathrm{g} / \mathrm{g}$ for the referents (table 1 ). There was a strong association between $\mathrm{T}-\mathrm{Pb}$ and $\mathrm{C}-\mathrm{Pb}$ levels $\left(\mathrm{R}^{2}=0.79\right)$ (figure 2 ).

Both the $\mathrm{T}-\mathrm{Pb}$ (figure 3 ) and $\mathrm{C}-\mathrm{Pb}$ levels increased with exposure time (data not shown). Moreover, for a given exposure time, the bone- $\mathrm{Pb}$ concentration tended to rise with the increasing current $\mathrm{B}-\mathrm{Pb}$ level.

There were close linear associations between both $\mathrm{T}-\mathrm{Pb}$ $\left[\mathrm{R}^{2}=0.78\right.$ (figure 4 ) $]$ and $\mathrm{C}-\mathrm{Pb}\left[\mathrm{R}^{2}=0.80\right.$ (data not shown)] on one hand, and cumB-Pb on the other. The strength of the associations decreased when cumB-Pb was exchanged for cumP-Pb $\left[\mathrm{R}^{2}=0.66\right.$ (figure 5) and $\mathrm{R}^{2}=0.63$ (data not shown), respectively].

In the linear regression analyses of $\mathrm{T}-\mathrm{Pb}$ (figure 6) and C- $\mathrm{Pb}$ (data not shown) versus adjusted cumP-Pb, the best fits $\left(R^{2}=0.79\right.$ and 0.82 , respectively) were obtained for bone-to-plasma half-times of 9 and 8 years, respectively (table 2). When the subject with the highest exposure was excluded, the half-times giving the best fits increased to 16 and 13 years, respectively.

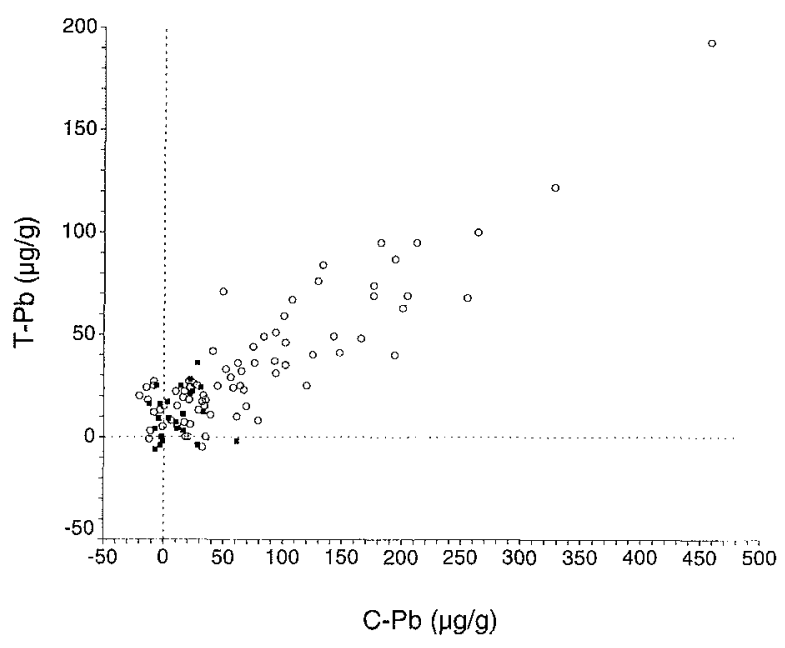

Figure 2. Lead concentrations in tibial ( $\mathrm{T}-\mathrm{Pb})$ and calcaneal $(\mathrm{C}-\mathrm{Pb})$ bone.
We also considered $\mathrm{T}-\mathrm{Pb}$ and $\mathrm{C}-\mathrm{Pb}$ in relation to the $\mathrm{ad}-$ justed cumB-Pb. However, the corresponding linear associations were not noticeably improved by the application of varying bone-to-blood half-times ( $\mathrm{R}^{2}$ became 0.79 for $\mathrm{T}-\mathrm{Pb}$ and 0.82 for $\mathrm{C}-\mathrm{Pb}$; the best fits were obtained for half-times of about 30 years).

\section{Discussion}

This study shows close associations between bone- $\mathrm{Pb}$ and cumB-Pb, in accordance with earlier observations $(6-8,12$, $15,16,20)$. However, the correlation, between bone- $\mathrm{Pb}$ and cumB-Pb, did not improve significantly when the latter was exchanged for adjusted cumP-Pb.

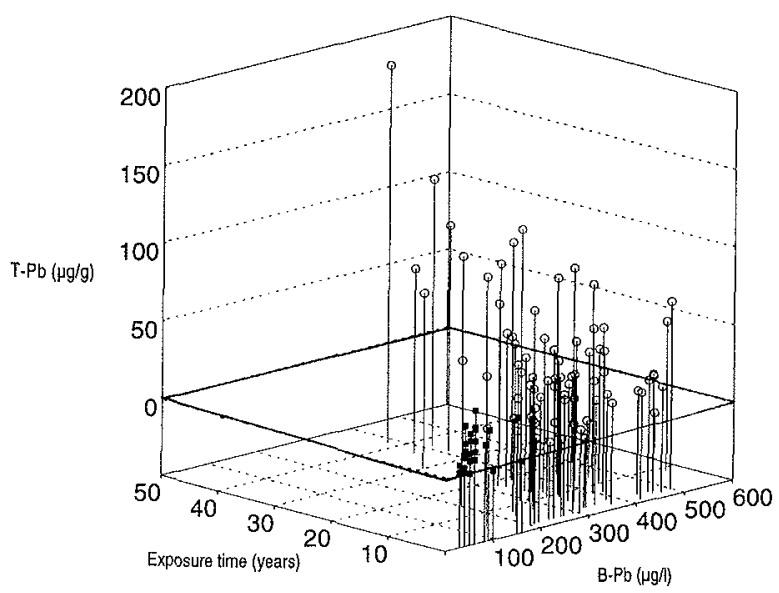

Figure 3. Lead concentrations in blood (B-Pb) and tibial bone (T$\mathrm{Pb}$ ) versus exposure time. The plotted $\mathrm{B}-\mathrm{Pb}$ value were measured on the same accasion as the bone-lead measurement. (circles = workers, squares $=$ referents)

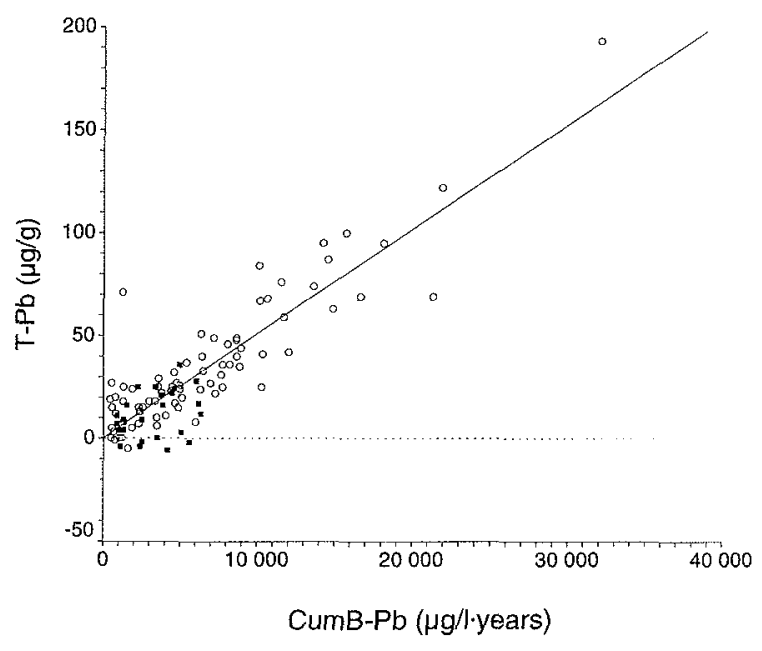

Figure 4. Lead concentrations in tibial bone $(T-P b)$ versus accumulated blood lead (cumB-Pb), the latter based on the annual mean blood-lead concentration. (open circles $=$ workers, closed squares $=$ referents) 


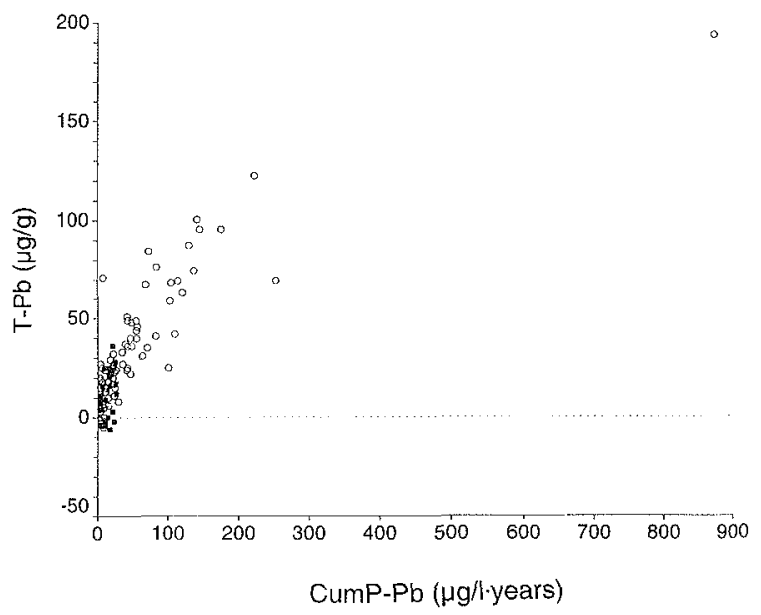

Figure 5. Lead concentrations in tibial bone (T-Pb) versus accumulated plasma lead (cumP-Pb), the latter based on the annual mean calculated plasma-lead concentration. (open circles $=$ workers, closed squares $=$ referents

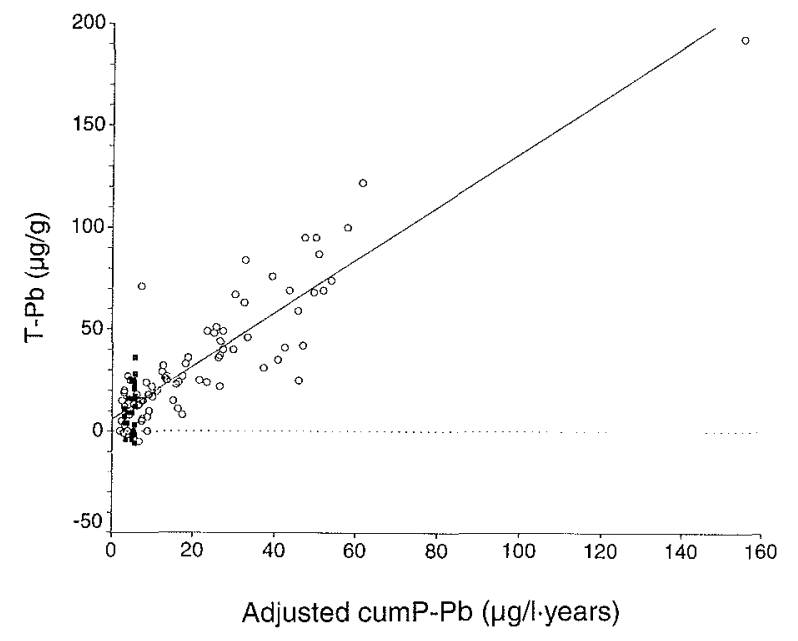

Figure 6. Lead concentrations in tibial bone $(\mathrm{T}-\mathrm{Pb})$ versus accumulated lead exposure based on adjusted annual plasma lead concentrations (cumP-Pb), calculated under the assumption of a 9-year bone-to-plasma half-time (open circles $=$ workers, closed squares $=$ referents).

\section{The use of plasma lead}

The use of $\mathrm{P}-\mathrm{Pb}$ instead of $\mathrm{B}-\mathrm{Pb}$ for the calculation of $\mathrm{cu}-$ mulative exposure increases the impact of high exposure, while the adjustment for a half-time decreases the impact of exposure long ago (which was generally higher than the more recent one). The adjustment for half-time (for which explained variance, $\mathrm{R}^{2}$, was employed as the goodness-of-fit statistics) results in an approximately rectilinear association between bone- $\mathrm{Pb}$ and adjusted cumP-Pb (figure 6). Surprisingly enough, the exchange of cumB-Pb for adjusted cumP-Pb did not enhance the correlation to bone- $\mathrm{Pb}$ noticeably. Moreover, the relation between bone- $\mathrm{Pb}$ and cumB- $\mathrm{Pb}$ was rectilinear, although it is reasonable to assume
Table 2. Variance explained $\left(R^{2}\right)$ by the linear regression of bone$\mathrm{Pb}(\mu \mathrm{g} / \mathrm{g})$ on an exposure index (adjusted CumP-Pb), calculated under different assumptions of the half-time of the annual amount of lead incorporated into bone (transfer from bone to plasma, see figure 1).

\begin{tabular}{lcc}
\hline $\begin{array}{l}\text { Bone-to-plasma } \\
\text { half-time (years) }\end{array}$ & \multicolumn{2}{c}{$R^{2}$} \\
\hline 5 & Tibial & Calcaneal \\
\hline 6 & 0.704 & 0.768 \\
7 & 0.749 & 0.802 \\
8 & 0.774 & 0.816 \\
9 & 0.786 & 0.818 \\
10 & 0.790 & 0.814 \\
11 & 0.789 & 0.807 \\
12 & 0.786 & 0.799 \\
13 & 0.781 & 0.790 \\
14 & 0.776 & 0.782 \\
15 & 0.771 & 0.774 \\
$\infty$ & 0.766 & 0.766 \\
\end{tabular}

that neither does $\mathrm{B}-\mathrm{Pb}$ (of which about $99 \%$ is in blood cells) predict the amount of lead incorporated into the skeleton, nor does the lead, once deposited, stay there forever. The latter rectilinear relation is probably explained by the fact that the amount of lead incorporated into the skeleton is underestimated at high $\mathrm{B}-\mathrm{Pb}$ values when cumB- $\mathrm{Pb}$ is used; this underestimate is counteracted by not taking into account the half-time of the lead in the skeleton.

We did not determine $\mathrm{P}-\mathrm{Pb}$ among the workers. In fact, a precise determination of the low concentrations in plasma has only recently become possible (22). Instead, we calculated the $\mathrm{P}-\mathrm{Pb}$ levels from the $\mathrm{B}-\mathrm{Pb}$ concentrations by use of the relationship between $\mathrm{B}-\mathrm{Pb}$ and $\mathrm{P}-\mathrm{Pb}$ derived from another study of lead workers, most of whom were from the same smelter as those in the present study. We believe this is a good way to generate information on $\mathrm{P}-\mathrm{Pb}$ in studies where it cannot actually be measured. There is no reason to believe that this relationship is not valid for recalculation of "historic" $\mathrm{B}-\mathrm{Pb}$ into $\mathrm{P}-\mathrm{Pb}$. It must, however, be stressed that the recalculations did not take into account any interindividual variation in the relation between $\mathrm{B}-\mathrm{Pb}$ and $\mathrm{P}-\mathrm{Pb}$. Therefore, the $\mathrm{P}-\mathrm{Pb}$ concentrations used are only substitutes for the true $\mathrm{P}-\mathrm{Pb}$ values. An interindividual variation by a factor of up to 2 may well be compatible with the variance in the relation between $\mathrm{B}-\mathrm{Pb}$ and $\mathrm{P}-\mathrm{Pb}$. We made an attempt to adjust for that difference among the 36 workers who participated both in this study and in the study of the relation between $\mathrm{B}-\mathrm{Pb}$ and $\mathrm{P}-\mathrm{Pb}$ (23). The variance in the relation between bone- $\mathrm{Pb}$ and adjusted cumP-Pb did, however, not decrease when their cumP-Pb values were adjusted for the ratio between the individuals' determined $\mathrm{P}-\mathrm{Pb}$ and the $\mathrm{P}-\mathrm{Pb}$ that could be calculated from the $\mathrm{B}-\mathrm{Pb}$.

\section{Skeletal half-time}

In the calculations of the cumulative exposure indices, we made assumptions regarding the $\mathrm{B}-\mathrm{Pb}$ levels during employment periods before 1968, as well as background $\mathrm{B}-\mathrm{Pb}$ level 
before the start of employment. This assumption may not be correct; for example, it is probable that the $\mathrm{B}-\mathrm{Pb}$ levels before 1968 were higher than we assumed. However, this difference would affect the half-times only slightly (8).

The half-times obtained in the present study were point estimates, based on the best fit to a linear correlation. The $\mathrm{R}^{2}$ value changed only marginally when different half-times were applied. Furthermore, the best fit is largely influenced by one single subject having higher lead levels than the other ones (figures 3-6). When this subject was excluded, the bone-to-plasma half-times increased considerably. Taken together with the marginal difference in $\mathrm{R}^{2}$ between different half-times, this finding illustrates the uncertainty in the estimate of the bone-to-plasma half-times.

To describe the relation between bone- $\mathrm{Pb}$, on the one hand and exposure time and $\mathrm{P}-\mathrm{Pb}$ on the other, a 3dimensional approach can be used under certain assumptions. Figure 7 illustrates the relation to $\mathrm{T}-\mathrm{Pb}$, obtained under the assumptions of a constant $\mathrm{P}-\mathrm{Pb}$ during the occupational exposure time (assumed to start at 18 years of age), and a tibia-to-plasma half-time of 9 years. The worker will always start at time $=0$ and $\mathrm{P}-\mathrm{Pb}=0.3 \mu \mathrm{g} / \mathrm{l}$ (assumed value; see reference 29 and figure 1 ); he will then have a $\mathrm{T}-\mathrm{Pb}$ of $6 \mu \mathrm{g} / \mathrm{g}$. (See the intercept in figure 6). Initially, the P-Pb concentration can rise very rapidly, while bone- $\mathrm{Pb}$ increases only slowly. Depending on the $\mathrm{P}-\mathrm{Pb}$, different workers will move along varying paths on the plane. The assumption of a constant P-Pb level makes it possible to use the present model without further assumptions regarding, for example, the size of the pools. (See the following discussion.)

We estimated the distribution rate constant for lead from bone to plasma. There is an important difference between the bone-to-plasma half-time and the terminal phase half-time estimated by repeated measurements in lead workers after exposure ceases. As there is a reincorporation of lead into the skeleton, the terminal phase half-time is longer than the bone-to-plasma one. However, an estimation of the impact of the reincorporation can be made by applying several assumptions to the model.

Under steady-state conditions (ie, after many years of lead exposure) the fractions of lead contained in the bone on the one hand and the blood and soft tissue on the other have been estimated to be about $92 \%$ and $8 \%$, respectively (3). Furthermore, in experiments with radiolabeled isotopes, $9-$ $12 \%$ of a single dose of lead was incorporated into bone between day 2 and day 20 , while excretion was assessed to be $14-15 \%$ through urine, and another $7-8 \%$ was excreted through feces (33). From this information, the reincorporation of lead into bone can be estimated to be 32 (range 28 36 )\% of the lead leaving the nonskeletal pool. To calculate the terminal phase half-time, these 2 assumptions were used. (See the appendix.)

Given the rapid excretion of lead from the blood [halftime 1 month (3)] and soft tissues (half-time 3 months, which is a reasonable value, resulting from the present model with

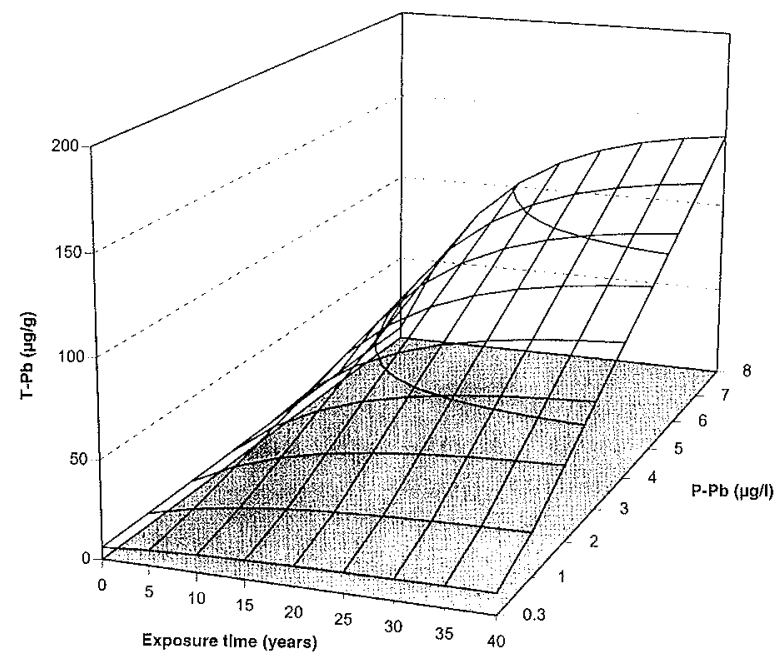

Figure 7. Theoretical relation between lead concentrations in tibial bone $(\mathrm{T}-\mathrm{Pb})$ and plasma $(\mathrm{P}-\mathrm{Pb})$ with respect to exposure time, under the assumptions that each worker's P-Pb is constant during exposure and the tibia-to-plasma half-time equals 9 years. It is further assumed that the exposure time starts at the age of 18 years and that the $\mathrm{P}-\mathrm{Pb}$ of an occupationally unexposed person is $0.3 \mu \mathrm{g} / \mathrm{l}$

the aforegiven assumptions, the model predicts that $97 \%$ of the body burden of lead would be in the skeleton and $3 \%$ in other tissues about 1 year after end of exposure (ie, during the terminal phase), which is also reasonable (34). Under the assumptions in the appendix, the terminal half-times are 13 years for tibia and 12 years for calcaneus ( 24 and 19 years) when the extreme values of one subject is disregarded).

The half-times of $13-24$ years for tibia and $12-19$ years for calcaneus are in reasonably good agreement with earlier estimates of 27 and 16, respectively, on the basis of the accumulation in bone with time (6). In addition, they fit the 16 years observed for fingerbone of retired lead workers (5). Furthermore, they are in accordance with the 19 years for fingerbone estimated by an identical $\mathrm{B}-\mathrm{Pb}$ model (8). That figure would, however, be expected to be lower if $\mathrm{P}-\mathrm{Pb}$ had been used. In view of the several assumptions and simplifications made in the model, and the fact that the study was made with subjects with some "background" lead exposure, this agreement is satisfactory.

It is, however, surprising that the estimated half-times do not differ more. The skeleton contains 2 types of bone tissue, trabecular and cortical bone, which represent 2 kinetically different metabolic compartments. The tibia shaft contains almost entirely cortical bone, while the calcaneus is almost entirely trabecular. Studies of lead in vertebra (20), which is one of the most typical trabecular bones, indicate a very rapid turnover (on the order of 1 year). In the present model, the sum of the flows of lead from both trabecular and cortical bone to plasma should determine the half-time resulting in an estimate between that for the 2 types of bone tissue. Perhaps the present model for calculating half-times is too dependent on a few heavily exposed subjects to give 
exact figures for the half-times. Another possible explanation for the similarity of the half-times in the present study is that the calcaneus, due to its carrying of the body weight, has a metabolism that differs from that of other trabecular bones.

\section{Extension of the model}

Considering the imprecision of bone- $\mathrm{Pb}$ measurements and the extremely simplified model (figure 2), it may not be very fruitful to extend the modeling to include more complicated exposure histories than a history of constant $\mathrm{P}-\mathrm{Pb}$ (figure 7). However, from the two-compartment model (figure 2) and the assumptions given in the appendix, it is possible to establish the relation between $\mathrm{P}-\mathrm{Pb}$, bone- $\mathrm{Pb}$, and exposure time with a certain exposure history. At the start of exposure, one has to assume a P-Pb level (eg, $0.3 \mu \mathrm{g} / 1)$ and bone- $\mathrm{Pb}$ level (eg, $\mathrm{T}-\mathrm{Pb}=6 \mu \mathrm{g} / \mathrm{g}$ ). By considering sufficiently fine subintervals of the total exposure time, then at each interval the lead incorporated into the central pool (due to external exposure), the transfer between the pools, and the excretion of lead can be assessed. Consequently, the $\mathrm{P}-\mathrm{Pb} / \mathrm{bone}-\mathrm{Pb}$ time course follows from stepwise numerical calculations. Thus, in practice, when a worker's bone- $\mathrm{Pb}$ and corresponding exposure time are known, his or her likely $\mathrm{P}-\mathrm{Pb}$ can be assessed retrospectively if the exposure history is relatively plausible (eg, $10 \%$ decrease during a particular calender year).

In conclusion, information on bone- $\mathrm{Pb}$ and exposure time can be used to assess past mean levels of $\mathrm{P}-\mathrm{Pb}$ and $\mathrm{B}-\mathrm{Pb}$. Such assessments may be of particular value in retrospective epidemiologic studies of long-term toxic effects. The present study gives information on how bone- $\mathrm{Pb}$ is related to $\mathrm{B}-\mathrm{Pb}, \mathrm{P}-\mathrm{Pb}$, and exposure time.

\section{Acknowledgments}

This work was supported by the Swedish Work Environment Fund, the National Swedish Environment Protection Agency, and the Medical Faculty of the Lund University.

The measurements of lead in bone were made in a collaborative project by Lilian J Sommervaille, $\mathrm{PhD}$, and Malcolm Scott, $\mathrm{PhD}$.

\section{References}

1. National Research Council (NRC), Committee on Measuring Lead in Critical Populations, Board of Environmental Studies, Commission of Life Sciences. Measuring lead exposure in infants, children, and other sensitive populations. Washington (DC): National Academy Press, 1993.

2. Legett RW. An age-specific kinetic model of lead metabolism in humans. Environ Health Perspect 1993;101:598-616.

3. Skerfving S, Nilsson U, Schiitz A, Gerhardsson L. Biological moni- toring of inorganic lead. Scand J Work Environ Health 1993;19 suppl 1:59-64.

4. Christoffersson J-O, Ahlgren L, Mattsson S, Schütz A, Skerfving S. Decrease of skeletal lead levels in man after end of occupational exposure. Arch Environ Health 1986;41:312-8.

5. Nilsson U, Attewell R, Christoffersson J-O, Schütz A, Ahlgren L, Skerfving $S$, et al. Kinetics of lead in bone and blood after end of occupational exposure. Pharmacol Toxicol 1991;68:477-84.

6. Gerhardsson L, Attewell R, Chettle DR, Englyst V, Lundström NG, Nordberg GF, et al. In vivo measurements of lead in bone in longterm exposed lead smelter workers. Arch Environ Health 1993; 48:147-56.

7. Christoffersson J-O, Schütz A, Ahlgren L, Haeger-Aronsen B, Mattsson S, Skerfving $S$. Lead in finger-bone analyzed in vivo in active and retired lead workers. Am J Ind Med 1984;6:447—57.

8. Börjesson J, Mattsson S, Strömberg U, Gerhardsson L, Schütz A, Skerfving $S$. Lead in fingerbone - a tool for retrospective exposure assessment. Arch Environ Health 1997;52:104-12.

9. Ahlgren L, Lidén K, Mattsson S, Tejning S. X-ray fluorescence analysis of lead in human skeleton in vivo. Scand J Work Environ Health 1976:2:82-6.

10. Börjesson J, Gerhardsson L, Mattsson S, Schütz A, Skerfving S, Österberg K. In vivo measurements of lead in fingerbone in active and retired lead smelters. Int Arch Occup Environ Health. 1997; 69:97-105.

11. Somervaille LJ, Chettle DR, Scott, MC. In-vivo measurement of lead in bone using $x$ ray fluorescence. Phys Med Biol 1985;30:929 - 43.

12. Somervaille LJ, Chettle DR, Scott MC, Tennant DR, McKiernan MJ, Skilbeck $A$, et al. In vivo tibia lead measurements as an index of cumulative exposure in occupationally exposed subjects. $\mathrm{Br} \mathrm{J}$ Ind Med 1988:45:174-81.

13. Somervaille LJ, Nilsson U, Chettle DR, Tell I, Scott MC, Schïtz A, et al. In vivo measurements of bone lead - a comparison of two $\mathrm{x}$-ray fluorescence techniques used at three different bone sites. Phys Med Biol 1989;34:1833-45.

14. Hu H, Milder FL, Burger DE. X-ray fluorescence measurements of lead burden in subjects with low-level community lead exposure. Arch Environ Health 1990;45:335-41.

15. Erkkilä J, Armstrong R, Riihimäki V, Chettle DR, Paakkari A, Scott $M$, et al. In vivo measurements of lead in bone at four anatomical sites: long term occupational and consequent endogenous exposure. Br J Ind Med 1992;49:631 - 44.

16. Roels H, Konings R, Green S, Bradley D, Chettle D, Lauwerys R. Time-integrated blood lead concentration is a valid surrogate for estimating the cumulative lead dose assessed by tibial lead measurement. Environ Res 1995;69:75-82.

17. Hu H, Payton M, Korrick S, Aro A, Sparrow D, Weiss ST, et al. Determinants of bone and blood lead levels among community-exposed middle-aged to elderly men: the normative aging study. Am J Epidemiol 1996;144:749—59.

18. Kim R, Hu H, Rotnitzky A, Bellinger D, Needleman H, Longitudinal relationship between dentin lead levels in childhood and bone lead levels in young adulthood. Arch Environ Health 1996;51:37582.

19. O'Flaherty EJ. Physiologically based models for bone-seeking elements. Toxicol Appl Pharmacol 1991;111:332 — 41.

20. Schütz A, Skerfving S, Christoffersson J-O, Ahlgren L, Mattsson S. Lead in vertebral bone biopsies from active and retired lead workers. Arch Environ Health 1987;42:340-6.

21. Hu H, Pepper L, Goldman R. Effect of repeated occupational exposure to lead, cessation of exposure, and chelation on levels of lead in bone. Am J Ind Med 1991;20:723-35.

22. Schiitz A, Bergdahl IA, Ekholm A, Skerfving S. ICP-MS determination of lead in plasma in lead workers and referents. Occup Environ 
Med 1996;53:736-40.

23. Bergdahl IA, Schütz A, Gerhardsson L, Jensen A, Skerfving S. Lead concentration in human plasma, urine, and whole blood. Scand J Work Environ Health 1997;23:359 - 63.

24. Bergdahl IA, Schütz A, Grubb A. Application of liquid chromatography-inductively coupled plasma mass spectrometry to the study of protein-bound lead in human erythrocytes. J Anal At Spectrom 1996;11:735-8.

25. Bergdahl IA, Grubb A, Schütz A, Desnick RJ, Wetmur JG, Sassa S, et al. Lead binding to d-aminolevulinic acid dehydratase (ALAD) in human erythrocytes. Toxicol Pharmacol 1997;81:153 - 8.

26. Somervaille LJ, Chettle DR, Scott MC, Krishnan G, Browne CJ, Aufderheide AC, et al. X-ray fluorescence of lead in vivo: simultaneous measurement of a cortical and a trabecular bone in a pilot study. In: Ellis KJ, Yasumura S, Morgan WD, editors. In vivo body composition studies. London: The Institute of Physical Sciences in Medicine, 1987:325-33.

27. Somervaille LJ, Chettle DR, Scott MC, Aufderheide AC, Wallgren $\mathrm{JE}$, Wittmers LE Jr, et al. Comparison of two in vitro methods of bone lead analysis and the implications for in vivo measurements. Phys Med Biol 1986;31:1267-74.

28. Strömberg U, Schütz A, Skerfving S. Substantial decrease of blood lead in Swedish children, 1978—94, associated with petrol lead. Occup Environ Med 1995;52:764-9.

29. Svensson BG, Björnham $\AA$, Schütz A, Lettewall U, Nilsson A, Skerfving $S$. Acidic deposition and human exposure to toxic metals. Sci Total Environ 1987;67:101—15.

30. Altman DG. Practical statistics for medical research. London: Chapman \& Hall, 1991:303—9.

31. Cake KM, Bowins RJ, Vaillancourt C, Gordon CL, McNutt RH, Laporte $\mathrm{R}$, et al. Partition of circulating lead between serum and red cells is different for internal and external sources of lead. Am J Ind Med 1996;29:440 -5

32. Bergdahl IA, Skerfving S. Partition of circulating lead between plasma and red cells does not seem to be different for internal sources of lead. Am J Ind Med 1997;32:317 — 8.

33. Heard MJ, Chamberlain $\mathrm{AC}$. Uptake of $\mathrm{Pb}$ by human skeleton and comparative metabolism of $\mathrm{Pb}$ and alkaline earth elements. Health Phys 1984;47:857-65.

34. Christoffersson J-O, Schïtz A, Skerfving S, Ahlgren L, Mattsson S. A model describing the kinetics of lead in occupationally exposed workers. In: Ellis KJ, Yasumura S, Morgan WD, editors. In vivo body composition studies. London: The Institute of Physical Sciences in Medicine, 1987:334-47.

\section{Appendix}

The following equations were derived from the model (figure 1) and used in the calculations of terminal-phase halftimes:

The relation between a half-time $\left(t_{1 / 2}\right)$ and a transfer rate constant $(\mathrm{k})$ is:

$$
\mathbf{t}_{1 / 2}=\ln 2 / \mathrm{k} \text {. }
$$

(equation 1)

The relation between the 2 pools is described by:

$$
\mathrm{k}_{12}=\mathrm{k}_{21} * \mathrm{~m}_{2 \mathrm{~s}-\mathrm{s}} / \mathrm{m}_{1 \mathrm{~s}-\mathrm{s}}
$$

where $k_{12}$ is the rate constant for transfer of lead from the nonskeleton to the skeleton pool, $\mathrm{k}_{21}$ is the rate constant for the transfer of lead from the skeleton to the nonskeleton pool, $\mathrm{m}_{2 \mathrm{~s}-\mathrm{s}} / \mathrm{m}_{1 \mathrm{~s}-\mathrm{s}}$ is the ratio between the lead contents in the pools at steady state. This value was set at $92 / 8$ (1).

The relation between the two rate constants for flow from the central pool are described by:

$$
\mathrm{k}_{12}=\mathrm{k}_{10} * \operatorname{REIN} /(1-\mathrm{REIN}),
$$

(equation 3)

where $\mathrm{k}_{10}$ is the rate constant for excretion of lead from the nonskeleton pool, REIN is the degree of reincorporation into the skeleton. This was set at 0.32 (2).
The relation between the lead contents in the pools during the terminal phase $\left(\mathrm{m}_{1 \mathrm{tp}} / \mathrm{m}_{2 \mathrm{tp}}\right)$ is given by the second order equation:

$$
\left(\mathrm{m}_{1 \mathrm{tp}} / \mathrm{m}_{2 \mathrm{pt}}\right)^{2}+\left[\mathrm{m}_{\mathrm{ttp}} / \mathrm{m}_{2 \mathrm{p}} *\left(\mathrm{k}_{12}+\mathrm{k}_{10}-\mathrm{k}_{21}\right) / \mathrm{k}_{12}\right]-\left(\mathrm{k}_{21} / \mathrm{k}_{12}\right)=0 .
$$

(equation 4)

The rate constant, $k_{t p}$, related to the terminal-phase half-time, is given by:

$$
\mathrm{k}_{21} * \mathrm{~m}_{2 \mathrm{tp}}-\mathrm{k}_{12} * \mathrm{~m}_{\mathrm{ttp}}=\mathrm{k}_{\mathrm{tp}} * \mathrm{~m}_{2 \mathrm{p}} .
$$

\section{References}

1. Skerfving S, Nilsson U, Schütz A, Gerhardsson L. Biological monitoring of inorganic lead. Scand J Work Environ Health 1993;19 suppl 1:59-64.

2. Heard MJ, Chamberlain AC. Uptake of $\mathrm{Pb}$ by human skeleton and comparative metabolism of $\mathrm{Pb}$ and alkaline earth elements. Health Phys 1984;47:857-65.

Received for publication: 11 March 1997 